\title{
The Construction of a Prehistory: The Austrian and German Social Democrats and the French Revolution
}

Alban Bargain, York University

Jean-Numa Ducange, La Révolution française et la social-démocratie: transmissions et usages politiques de l'histoire en Allemagne et Autriche, 1889-1934 (Rennes: Presses universitaires de Rennes, 2012)

\section{Introduction}

As its title indicates, Jean-Numa Ducange's first book is simultaneously a work of transnational and one of comparative history. La Révolution française et la socialdémocratie studies the influence of the French Revolution on the Social Democratic Party of Germany (SPD - Sozialdemokratische Partei Deutschlands) and the Social Democratic Party of Austria (SDAPÖ - Sozialdemokratische Partei Österreichs) from 1889, the last year of Bismarck's Anti-Socialist Laws, until the outlawing of the SDAPÖ, in February 1934. Founded in 1890, the SPD, which still exists to this day, has dominated the German Left for most of the twentieth century. Similarly, the SDAPÖ (founded in 1889) and now known as the SPÖ (Sozialdemokratische Partei Österreichs), has been a fixture in Austrian politics for more than a hundred years. Although the 1890s inaugurated an era of increasing political legitimacy for the SPD and the SDAPÖ, it took the two socialist traditions almost fifty years to reconcile their different schools of socialism.

Not surprisingly, these parties' ideological platforms have changed greatly since the period under study. In the late nineteenth century, the Austrian and German Social Democratic parties were dominated by Marxist ideas. They gradually moved away from Marxism in the interwar period and eventually shed most of what was left of that ideology after the Second World War.

In the course of this work, Ducange not only examines the appropriation and, to some extent, the invention of traditions, but also attempts to compare two political organisations whose histories paralleled each other but differed in many regards. The book describes the Social Democrats' efforts to legitimise their parties by establishing ideological links with figures, events, and movements of the French Revolution as a "moment important de l'histoire du marxisme et des traditions d'interprétations de la Révolution française."1 Most notably, the debates that took place regarding that event's place within the SPD and the SDAPÖ mirrored the ideological heterogeneity that characterised the European socialist parties of that period. 
The layout of La Révolution française rests on a three-pronged design. While its overall structure is organised chronologically, each chapter includes thematic and prosopographical sections. Throughout his study, Ducange uses the works of Karl Kautsky, a major Social Democrat leader and thinker, as a means to assess the roles that the French Revolution fulfilled in the two parties.

However, La Révolution française does more than merely describe the debates that were taking place among party leaders and intellectuals. Based on impressive research, this work also explores the uses of that event as an instrument of communication and education in Social Democratic circles.

\section{A Multilayered, Ambitious Work}

The events that unfolded in the Twentieth century have changed Germany's national narrative in so many ways that the first half of the Nineteenth century ended up being obscured as a result. However, it has to be recognised that the early nineteenth century undoubtedly saw the genesis of the economic and, ultimately, political unification of the German states. The World Wars, the Nazi regime, and the Cold War experiences have, justifiably, led historians of Germany and, more generally, the media, to explain anew the trajectory of German history and formulate new narratives. This focus on the short Twentieth century, whose ending has been symbolically defined by the fall of the Berlin Wall, has weakened the centrality of the Nineteenth-century as the crucible of the German nation-building process and turned the 1914-1989 era into one of (re-)definition of what constitutes modern Germany.

Nevertheless, historians of Germany and Austria have not forgotten the early Nineteenth century. Scholars like David Blackbourne, Geoff Eley, Tom Taylor, and others have written extensively on the long nineteenth century (17891914) in Germany and its impact on that country's national project. ${ }^{2}$ As far as Austria is concerned, Barbara Jelavich, Steven Beller, and many more have efficiently analysed that country's trajectory, from its position as leading power within a multiethnic empire in the early Nineteenth century to that of unilingual republic in the wake of the First World War. ${ }^{3}$ That said, many of those historians' works have, understandably been coloured by their own Twentieth-century experiences.

The books and articles produced during that era, and even in the last two decades were, in many ways, the products of their own day and age. The historiographical debates that took place in the second half of the twentieth century were dominated by questions related to changes and continuities in German history, which pitted the proponents of the Sonderweg (special path) against those who opposed that view. Much ink has been spilled on Sonderweg, a generic label 
applied to historical theories that consider Germany to have followed a peculiar, unique historical path. The frequent interweaving of the two countries' histories has contributed to add complexity to these debates. In addition to the historical and geographical intricacies of the Sonderweg debates, the relatively fresh memory of the Second World War and its impact on Austria and Germany underlay much of the historical scholarship produced during the Cold War and even after.

While Ducange belongs to a generation of scholars that came of age after the short twentieth century (1914-1989), his study of the SPD's and the SDAPÖ's uses of the French Revolution indirectly participates in the discussion on the German nation-building experience and, more broadly speaking, that of Deutschtum (Germanness). More than yet another book on Social Democracy, La Révolution française deals with two critical, formative periods of German history. In the course of the Second Reich (1871-1918) and of the Weimar Republic (1918/19-1933), Germany was still in the process of national formation. The political, (sub-)cultural, and religious tensions between the central government in Berlin and many of the states that composed the federation riddled the country until at least 1945, when the Cold War introduced an additional cleavage - one of an ideological nature. Although the book does not focus on that aspect of German history, several of the themes discussed in it tackle the issue of national memory, the appropriation of foreign events and their mythologizing. In that regard, the study of the SPD and its efforts to appropriate the French Revolution sheds some light on both ideological and national legitimization processes.

While Ducange barely mentions the Sonderweg controversy, his work indirectly and perhaps unintentionally explores the lasting impact of the French Revolution on the construction of a German national consciousness. In that regard, the Austrian and German brands of Social Democracy constitute perfect, albeit paradoxical, case studies. In their own ways, the two parties exemplify the attempts made by many parties and various groups, in Austria as in Germany, to make sense of their respective countries' histories. The fact that the SPD and the SDAPÖ were essentially internationalist parties makes their interest (even qualified) in the German national project even more interesting. Ducange, though non-verbose on that aspect of his work, reminds us that the German national question was not confined to the various patriotic organisations and circles that sprung out in the course of the nineteenth century, but also arose in socialist circles. ${ }^{4}$

One of the many strengths of La Révolution française, then, is its subtle analysis of two parties whose identities were simultaneously German or Austrian and socialist/social democratic. The importance of the revolutionary and national pasts in the SPD's quest for legitimacy certainly adds an interesting angle to 
the early Sonderweg approach. Indeed, the SPD participated in the construction of an image of Germany that was rooted in the context of a Europe inflamed by the French Revolution. It may seem, at first, that the Social Democrats' (and many of their opponents') understanding of modern Germany as having been the result of the Napoleonic Wars implicitly rooted the nation-building project in a series of events of a transnational, all-European nature.

However, it would be unfair to assume that the German Social Democrats viewed the path that led to German unification as having originated in an all-European conflict and, as a result, as not being "special" at all. The SPD's and the SDAPÖ's views on the French Revolution were, to say the least, ambiguous. To Ducange, the pre-First World War SPD's status as an "[o]rganisation de masse représentant une partie grandissante de la population allemande," led it to become a Volkspartei (a "people's party") before it officially recognised itself as such during the Weimar Republic. ${ }^{5}$ On the one hand, the connection between what was constructed as the modern German national project and the new European balance of power that emerged in 1815 endowed that country's pre-unification era with transnational, not-so-peculiar characteristics. However, by the eve of the First World War, the Social Democrats had developed a synthetic view on the nature of their party and its relationship to Germany as a whole. Whereas the 1789-1792 legacy, acknowledged as having originated on the other side of the Rhine, occupied an important place in the SPD's and the SDAPÖ's respective narratives, the two parties were keen to distinguish their respective experiences from the French one. Far from idealising the French brand of republicanism, the two parties tended to favour alternatives to that model. To the Social Democrats, then, those alternatives had to agree with these two countries' natural political structures. ${ }^{6}$

As far as the Austrian side of the comparison is concerned, it is obvious that Ducange dealt with a political and socio-cultural context that differed substantially from that of Germany. Although the Austrian Empire had undergone a substantial administrative reform in the wake of its 1866 defeat to Prussia, thereby becoming Austria-Hungary, it was still considered a great power in nineteenth-century Europe. Ducange thus had to face a triple challenge. Firstly, while Germany was experiencing its unification process, Austria-Hungary had long been a major, well-established player in international affairs. Secondly, the SDAPÖ was, from its founding onward, forced to adapt to the various nationalities that composed the Austro-Hungarian Empire. ${ }^{7}$ As a result, Ducange had to take into account the challenges inherent to comparing legitimisation processes in an already established multinational entity with those taking place in a country that had freshly experienced political unification. Finally, the French 
Revolution did not have as important an impact on Austria as it did on Germany. For these reasons, a comparative study of the SPD's and the SDAPÖ's uses of the French Revolution is bound to be dissymmetrical.

However, conceptual dissymmetry does not invariably constitute a weakness and, in some cases, is the sine qua non condition for an efficient comparative study. In the present case, Ducange certainly tried to bite off more than he (or any other historian) could chew. The Austro-Hungarian Empire would in itself have constituted an interesting case study of a party attempting to define its purpose and forge its official rhetoric in a multinational country. However, such a study would have had to end in 1919, when the Austrian Republic was founded as a consequence of the collapse of the Austro-Hungarian Empire. Since Ducange's book straddles the pre- and post-First World War eras, a focus on the challenges that the SDAPÖ faced in relation to non-German-speaking groups in the Empire would certainly have led to unnecessary digressions. That said, the absence of any mention of the Adriatic Italian Section of the Social Democratic Workers' Party of Austria, of the Ukrainian Social Democratic Party or of other autonomist tendencies within the Austro-Hungarian socialist movement is a little problematic.

\section{The Social Democrats and the French Revolution: A Love-Hate Relationship}

The interest of the SPD and the SDAPÖ in the French Revolution was twofold. Firstly, as Marxist organisations, the two parties sought to present the Revolution as a major $\operatorname{cog}$ in the dialectical process underlying historical development. As the historical moment that saw the political advent of the bourgeoisie, the French Revolution was, as a result, simultaneously praised as the necessary condition for future, purely proletarian upheavals, and criticised as the reign of the capitalist class. As a result, the event served to emphasise the continuities and changes (for the best) in the forces of progress throughout history.

Secondly, the understanding of the French Revolution as a world-historical moment in socialist history led the two parties to partake in the mythologising of their respective nations. The most glaring example of such efforts to combine the legacy of the Revolution with the emancipating nature of German unification is that of the Social Democrats' perspective on the later, Napoleonic phase of the event. From the early 1890s until the early 1910s, the years 1800-1815 were not usually recognised by the parties' theorists as being part of the Revolution. Nevertheless, the Social Democrats acknowledged that Napoleon's action had been decisive in exporting the revolutionary legacy to the German states. As Ducange phrases it in his conclusion to a section on the centenary of 
the 1813 War of Liberation, a phase of the War of the Sixth Coalition, "[1]'occupation napoléonienne s'étant rapidement transformée en domination étrangère, 1813 est situé au même niveau que la prise de la Bastille en 1789. A quelques mois d'août 1914, les sociaux-démocrates assument à leur manière un héritage national qui se combine, non sans ambiguïtés, avec les références révolutionnaires traditionnelles." 8 The commemoration of the War of Liberation thus gave the German Social Democrats the opportunity to reconcile the dialectical interpretation of the French Revolution with that of the national past.

Not surprisingly, the First World War saw the confrontation of two main attitudes towards Social Democracy's revolutionary heritage. On the one hand, anti-French (and, sometimes, antiwar) sentiment within the SPD encouraged some of its leaders and propagandists to draw parallels between 1914 France and the Jacobin, bourgeois, warlike nature of revolutionary France. ${ }^{9}$ The emphasis on the negative facets of the French Revolution did not emerge out of thin air, in that they complemented the Social Democrats' attitude during the commemoration of the 1813 War of Liberation. Curiously, however, Ducange does not explore the 1813-1914 parallelism further. On the other hand, some Social Democrats abided by a positive view of the French Revolution. For instance, the case of Alsace-Lorraine in the 1790s, where some German and French revolutionaries worked together, was used to make a case for the universalist, essentially progressive nature of the Revolution. ${ }^{10}$

Unfortunately, Ducange is less verbose on the SDAPÖ's views on the commemoration of the 1813-15 War. However, although the absence of a truly synthetic section comparing the two parties during the First World War is problematic, the part devoted to the Austrian Social Democrats in the wartime era is as helpful as it is brief. In Austria-Hungary, the ambiguity regarding the memory of the French Revolution seems to have been similar, in several respects, to the one that was at play in Germany. Like their German counterparts, some factions in the Austrian party proved inclined to resorting to a pro-French Revolution rhetoric. Led by Friedrich Adler, the leader of the party's leftwing, "internationalist" tendency, the antiwar Social Democrats opposed the "social patriots". Adler refused to equate 1789 with 1914. To him, "la bourgeoisie a définitivement rompu avec les traditions de 1789, mais dans le prolétariat elles ont vécu au moins jusqu'au début de cette guerre."11 In Austria-Hungary as in Germany, then, the Social Democrats were divided in their attitudes towards the French Revolution. However, that cleavage did not develop along the same lines as the pro- and antiwar factions that sprung up within the two parties during the First World War. 
As mentioned in this essay's introduction, Ducange chose Karl Kautsky as his book's central thread. The implicit choice of Kautsky's intellectual trajectory as an indicator of the SPD's (and, to some extent, of the SDAPÖ's) official stances on the Revolution is appropriate in several ways. A prolific writer, Kautsky played a decisive part in constructing the SPD's various perspectives on the Revolution. Along with other Marxist orthodox thinkers, Kautsky applied Marx's and Engels' scientific reading of history to that particular period.

Secondly, Kautsky could be seen as a symbolic link between the German and Austrian brands of Social Democracy. Born in Prague in 1854, he joined the Austrian Social Democrats in the 1870s and, in the 1880s, the German Socialist Workers' Party (SAPD - Sozialistische Arbeiterpartei Deutschlands), the German predecessor of the SPD during the Anti-Socialist Laws. It was during the 1880s that he befriended Friedrich Engels, August Bebel, and other prominent socialist figures and became an expert in Marxist theory.

Thirdly, Kaustsky straddled several key periods of socialist history. Throughout his career, he never ceased to apply Marxist theory to every subject. This loyalty to the Marxist gospels earned him the nickname of "pape du marxisme."12 His work on the French Revolution provided him with an ideal opportunity to argue for a class-based analysis of the event, an approach that contrasted sharply with that of Ferdinand Lassalle, whose more conservative brand of socialism placed more emphasis on the fourth estate. Indeed, the latter did not correspond to Marx's and Engels' definition of the proletariat as a social class alienated from the means of production. In essence, Lassalle's fourth estate consists of "the disinterested class of the community, which sets up and can set up no further exclusive condition, either legal or actual, neither nobility nor landed possessions nor the possession of capital, which it could make into a new privilege and force upon the arrangements of society." 13 Clearly, then, Lassalle's definition of social class, which he uses interchangeably with estate, is broader than the Marxist one in that it includes craftspeople as well as salaried workers. Thus, Kautsky's reading of the Revolution not only contributed to construct a Marxist reading of the event, but also had tactical purposes, including that of rooting out the relics of the late Lassalle's ideas, which had dominated German socialism from the 1860 s to the mid-1870s.

In addition to enriching the Marxist understanding of the French Revolution, the Social Democratic theorists engaged in selecting the aspects of the period that the two parties could either appropriate or demonise. In that regard, the initial privileging of $1789-94$ as a time frame was symbolic of the SPD's and the SDAPÖ's partisan portrayals of major figures and events. 
However, the periodisation changed over time, to the point that the Social Democrats occasionally extended their time frame to include the Napoleonic era until 1813, when the occupation of the German states ended. The propagandists also created a veritable pantheon, comprising several female figures, like Olympe de Gouges or Marie-Jeanne Roland, and (usually male) heroes and villains.

Among the latter, Robespierre held the role of the tyrant who contributed to ending the progressive drive of the Revolution. On the other hand, Paul Marat, Gracchus Babeuf and Paul Hébert were often seen as positive figures, especially in the pre-First World War era. ${ }^{14}$

But aside from the Social Democratic leaders' selective uses of the French Revolution, the latter was part and parcel of the broader issue of the place of dialectical materialism and class struggles in history. In that regard, Ducange's analysis of his topic's spatial dimension is extremely useful, in that it provides an interesting perspective on the theoretical and structural divergences that separated the Austrian and German Social Democrats from the French socialists. Except for the Guesdists (the name given to the French Marxists), the French socialists' views on the Revolution were not so much influenced by Marxist philosophy.

Ducange successfully shows that the evolution of the two parties' respective approaches to the French Revolution can serve as an indicator of the changes in their ideological stances. To be more precise, Ducange sees an initial period of interest in the Revolution that began in 1889, a key year in that it coincided with the centenary of 1789 , the founding of the Second International, and the imminence of the lifting of Bismarck's Anti-Socialist Laws. Between 1895 and the mid-1900s, the references to the Revolution knew a decline, mostly due to the cleavage between orthodox Marxists and the reformist and revisionist wings of the two parties. A rigidifying of the (majority) orthodox Marxist branch of the party ensued. Headed by Kautsky, that faction resisted the introduction of a bourgeois/republican reading of the Revolution, which partly contradicted Marx's view that historical development followed a dialectical course. Not surprisingly, then, the works of Jean Jaurès, one of France's most prominent socialist leaders, met with hostility from SPD and SDAPÖ intellectuals and leaders. Based on a synthetic view of historical development inspired by evolutionary and materialist philosophies, Jaurès saw the Revolution as a generally positive historical moment that was linked with late-nineteenth century socialism. By contrast, the official Marxist stance conceived of the French Revolution as a historical stage dominated by the bourgeoisie and whose function was to carry the seed of the modern proletariat. ${ }^{15}$ More than purely philosophical, the debates on the place and nature of the Revolution had immense political implications, one of which was the question of alliances with bourgeois parties. 
The 1905 Russian Revolution contributed to a new interest in the French Revolution. That period was marked by questions regarding the imminence of a truly proletarian upheaval. Finally, the revolutions of 1917 ushered a new era in the two parties' perspectives on the event, more specifically regarding the question of the use of violence. In that regard, the splits that divided the Marxist left and resulted in the creation of communist parties encouraged the Social Democrats to mark their difference from Bolshevism by using the Reign of Terror (1793-94) as a cautionary tale.

Ducange's analysis is not confined to the SPD's and the SDAPÖ's elite perspectives on the revolutionary legacy. Although the two parties' leaderships and intelligentsias defined the ways in which the 1789-1813 era was interpreted, efforts were made to educate the labouring masses on that particular period of history. The decision to create Parteischulen ("Party Schools"), in 1906 in Berlin and in 1910 in Bodenbach, Austria (now Děčín, Czech Republic), did not just stem from ideological considerations on the need to democratise knowledge. The growing popularity of the two parties at the turn of the twentieth century required them to train new officers and executives, especially at the local level.

As Ducange rightly points out, while the Social Democratic educational organisations proposed courses on a vast array of subjects, history and, more specifically, the French Revolution, occupied an important place in those schools' curricula. Although the SPD's Party School seems to have granted more room to the teaching of that topic than its Austrian counterpart did, this part of the book takes a broad approach to the two organisations' views on popular education. Indeed, Ducange does not focus his analysis solely on the Party Schools, but on other means of spreading knowledge, such as conference tours, slideshows, and party libraries. ${ }^{16}$

Although popular education as a vector for party legitimisation gained in importance in the 1900s, the question of the democratisation of knowledge as a prerequisite to the establishment of socialism dated back to the early 1860 s, when the German socialist movement was dominated by Lassalle's ideas. Lassalle played a major role in developing the idea of Bildung in Social Democratic circles. Understood in the context of the Social Democratic subculture, the concept of Bildung, generally translated as "education" or "learning", could be defined as a democratisation of "l'idéal classique des Grecs du développement des facultés individuelles, idéal que la bourgeoisie aurait réservé à une toute petite minorité." 17 The teaching of history, and especially of periods that were believed to have played key roles in the development of socialist ideas, was, as a result, part and parcel of Bildung. Thus, it was logical that the teaching of the French Revolution should have held a place of choice in the two parties' communication 
and educational methods. ${ }^{18}$

Finally, the legacy of 1789 contributed to strengthening Social Democracy's more or less invented traditions. Indeed, beyond the realm of theory and history, many aspects of the French Revolution were incorporated into the SPD's and the SDAPÖ's subculture. The May Day ritual, for instance, though it originated in the United States and was officially adopted by the Second International in 1889, was often linked with the events of $1789 .{ }^{19}$ The Social Democratic press and local sections also regularly appropriated the Revolution's lyrical repertoire. Thus, the Arbeitermarseillaise ("Workers' Marseillaise") and the Lassalleaise were set to the tune of Rouget de Lisle's Marseillaise. ${ }^{20}$

\section{Conclusion}

In conclusion, La Révolution française et la social-démocratie is extremely well written and well structured. Aside from a small number of references that might seem arcane to those unfamiliar with the French Revolution or the history of Marxism, Ducange's prose is jargon-free and engaging. That said, some familiarity with modern European political history and with some of Marx's and Engels' works, such as The Eighteenth Brumaire of Louis Napoleon and The Civil War in France, is required.

Ducange uses a vast array of sources, such as brochures, plays, contemporary scholarly works, epistolary correspondences, newspapers, study group programmes, and calendars. The research is impressive and the examples chosen by the author are of particular interest. From a thematic viewpoint, Ducange covers many facets of the subject, such as that of the emancipation of women, the interplay between memory and political identity, and the dilemmas posed by the issue of patriotism in an essentially internationalist party.

The only major shortcoming of the book has to do with its comparative aspect. Whereas Ducange successfully analyses the uses of the French Revolution by the SPD, his exploration of the same process in the SDAPÖ is not as thorough. Granted, the author explains that lopsidedness by the fact the Austrian Empire had not felt the consequences of the Revolution as much as the German states. ${ }^{21}$ However, a deeper analysis of the changes that affected the party's references to the Revolution in the wake of the 1918-19 insurrections in Budapest and Vienna would have been helpful. Finally, another aspect that could have been further strengthened concerns the book's theoretical premise. For instance, Ducange's sporadic references to Eric Hobsbawm's edited work The Invention of Tradition could have been further expanded. 
Notwithstanding those weaknesses, La Révolution française et la social-démocratie is an important book that not only consists in a solid inquiry into the world of European socialism, but also adds fresh perspectives to our knowledge on the political uses of the past in general. While other works have dealt with the Marxist left's quest for legitimacy through the appropriation of the French Revolution (see, for instance, the works of Tamara Kondratieva and Danielle Tartakowsky), Ducange's book raises a host of questions on the current nature of German and, more generally, European social democracy. 


\section{NOTES}

1 Jean-Numa Ducange, La Révolution française et la social-démocratie: transmissions et usages politiques de l'bistoire en Allemagne et Autriche, 1889-1934 (Rennes: Presses universitaires de Rennes, 2012), 19-20.

2 See David Blackbourne and Geoff Eley, The Peculiarities of German History: Bourgeois Society and Politics in Nineteenth-Century Germany (Oxford: Oxford University Press 1984); Tom Taylor, "Images of Youth and the Family in Wilhelmine Germany: Toward a Reconsideration of the German Sonderweg," German Studies Review 15, German Identity (Winter 1992): 55-73.

${ }^{3}$ See Barbara Jelavich, Modern Austria: Empire and Republic, $1815-1986$ (Cambridge: Cambridge University Press, 1987); Steven Beller, A Concise History of Austria (Cambridge: Cambridge University Press, 2006).

${ }^{4}$ Ducange, Révolution française, 214.

5 Ibid.

6 Ibid., 210-219.

7 Stanley Z. Pech, "Political Parties among Austrian Slavs: A Comparative Analysis of the 1911 Reichsrat Election Results," Canadian Slavonic Papers / Revue Canadienne des Slavistes 31, no. 2 (June 1989): 172-76, 178-79.

${ }^{8}$ Ducange, Révolution française, 218.

9 Ibid., 217-22.

10 Ibid., 223-224.

11 Ibid., 223.

12 Ibid., 50.

13 Ferdinand Lassalle, Working Man's Programme, trans. Edward Peters (London: The Modern Press, 1884), 43-44; Ducange, Révolution française, 33, 52.

14 Ducange, Révolution française, 34, 60-61.

15 Ibid., 109.

16 Ibid., 167-84.

17 Ibid, 32.

18 Ibid., 31-32.

19 Ibid., 76-77, 80.

20 Ibid., 63-64.

21 Ibid., 175-76. 